\title{
Diversity and Structure of Natural Regeneration in Swamp Forests in Southeastern Brazil
}

\author{
Marly Antonielle Ávila ${ }^{1}$ \\ Nayara Mesquita Mota² (B) \\ Saimo Rebleth Souza ${ }^{1}$ (D) \\ Rubens Manoel dos Santos ${ }^{3}$ (1) \\ Yule Roberta Ferreira Nunes ${ }^{1}$ (I)
}

\begin{abstract}
Many factors can influence the structures and distributions of plant communities. Plant diversity of swamp forests reflect responses to water stress conditions. We evaluated the floristic diversity, structure, and composition of the regenerating shrub-tree species of six swamp forests in veredas ecosystems (northern Minas Gerais, Brazil), and the floristic similarities between them. All individuals $\geq 1 \mathrm{~cm}$ in diameter at ground level and $<3 \mathrm{~cm}$ in diameter at breast height were sampled in one hundred $25 \mathrm{~m}^{2}$ plots in each area. A total of 5442 individuals were recorded, distributed among 134 species, 85 genera, and 47 botanical families, with a diversity (Shannon) of 3.38 and equability (Pielou) of 0.69. Beta diversity was high, while similarities between the areas were low, with only two species common to all six sites. The forests showed different compositions, diversities, and natural regeneration structures, reflecting their ecotone nature and past anthropic impacts.
\end{abstract}

Keywords: Flooded Areas, Juveniles, Phytosociology, Succession, Vereda.

\section{INTRODUCTION}

The Brazilian Cerrado (neotropical savanna) constitutes a mosaic of several phytophysiognomies (Fernandes et al., 2016). Veredas (palm swamps) ecosystems are complex systems associated with Cerrado watercourses (Bijos et al., 2017). They are characterized by the presence of the palm tree Mauritia flexuosa L.f. (Arecaceae), "buriti", which grows in water-saturated sites and are of great importance to biodiversity (Endress et al., 2017). Depending on the ages of those systems, swamp forests will develop in their lower sections and demonstrate successional stage changes (Boaventura, 2006), although few studies have yet been undertaken in areas of swamp forests to examine that phenomenon (Nunes et al., 2015) while focusing on their regenerative strata (Ávila et al., 2016).
Natural regeneration refers to forest growth from the initial stages of establishment and development (Pastório et al., 2018), and describes gradual processes that can restore the structure, function, and composition of an ecosystem to its pre-disturbed state (Chazdon \& Guarigata, 2016). That regeneration is shaped by natural socio-ecological processes, but can be sustained, improved, or impaired over time through human interventions (Chazdon et al., 2014). Studies of the regenerative strata allow insights into their potential for regeneration and for the success of environmental restoration efforts (Menino et al., 2012); such studies are also fundamental to establishing economic strategies for forest management and conservation (Santos et al., 2017).

Veredas are important environments to study considering their low resilience, degrees of anthropization, and ecosystem complexity (soil, topography, and composition) (Oliveira et al.,

${ }^{1}$ Universidade Estadual de Montes Claros (UNIMONTES), Departamento de Biologia Geral, Laboratório de Ecologia Vegetal, Montes Claros, MG, Brasil

${ }^{2}$ Inhotim Cultural, Brumadinho, MG, Brasil

${ }^{3}$ Universidade Federal de Lavras (UFLA), Departamento de Ciências Florestais, Lavras, MG, Brasil 
2009). Plant diversity tends to be low in those water-stressed environments due to environmental constraints associated with soil saturation (Parolin et al., 2010), although high diversity may occur on a regional scale due to their natural isolation.

The present study sought to examine the floristic compositions of six swamp forests in northern Minas Gerais State, analyze their natural regeneration and vegetation similarities, as well as address the following questions: (i) how does the diversity and composition of those swamp forests vary?; (ii) is there high floristic similarity between the study sites?; and, (ii) is local diversity ( $\alpha$ diversity) lower than the diversity between areas ( $\beta$ diversity)?

\section{MATERIALS AND METHODS}

\subsection{Study area}

The present study was carried out in the Pandeiros River Environmental Protection Area (EPA) in northern
Minas Gerais State, in southeastern Brazil. The EPA covers an area of 393,060 ha and includes the entire Pandeiros River basin, within the municipalities of Januária, Bonito de Minas, and Cônego Marinho (Nunes et al., 2015). The regional climate is tropical humid and dry (type Aw according to the Köppen classification system), with well-defined dry winters and rainy summers (Alvares et al., 2014). Our sampling focused on regenerating arboreal and shrub vegetation in six swamp forest: Água Doce (AD), Almescla(AL), Buriti Grosso (BG), Capivara (CA), Pindaibal (PI), and São Francisco (SF) (Fig. 1; Tab.1).

The vegetation in the study area is represented by Cerrado and Caatinga transition phytophysiognomies, culminating in a mosaic of riparian and dry forests, savanna, and palm swamps (Menino et al., 2012). The swamp forests associated with the palm swamps, the target of this study, occur mainly in the upper-mid Pandeiros River basin (Nunes et al., 2009; 2015).

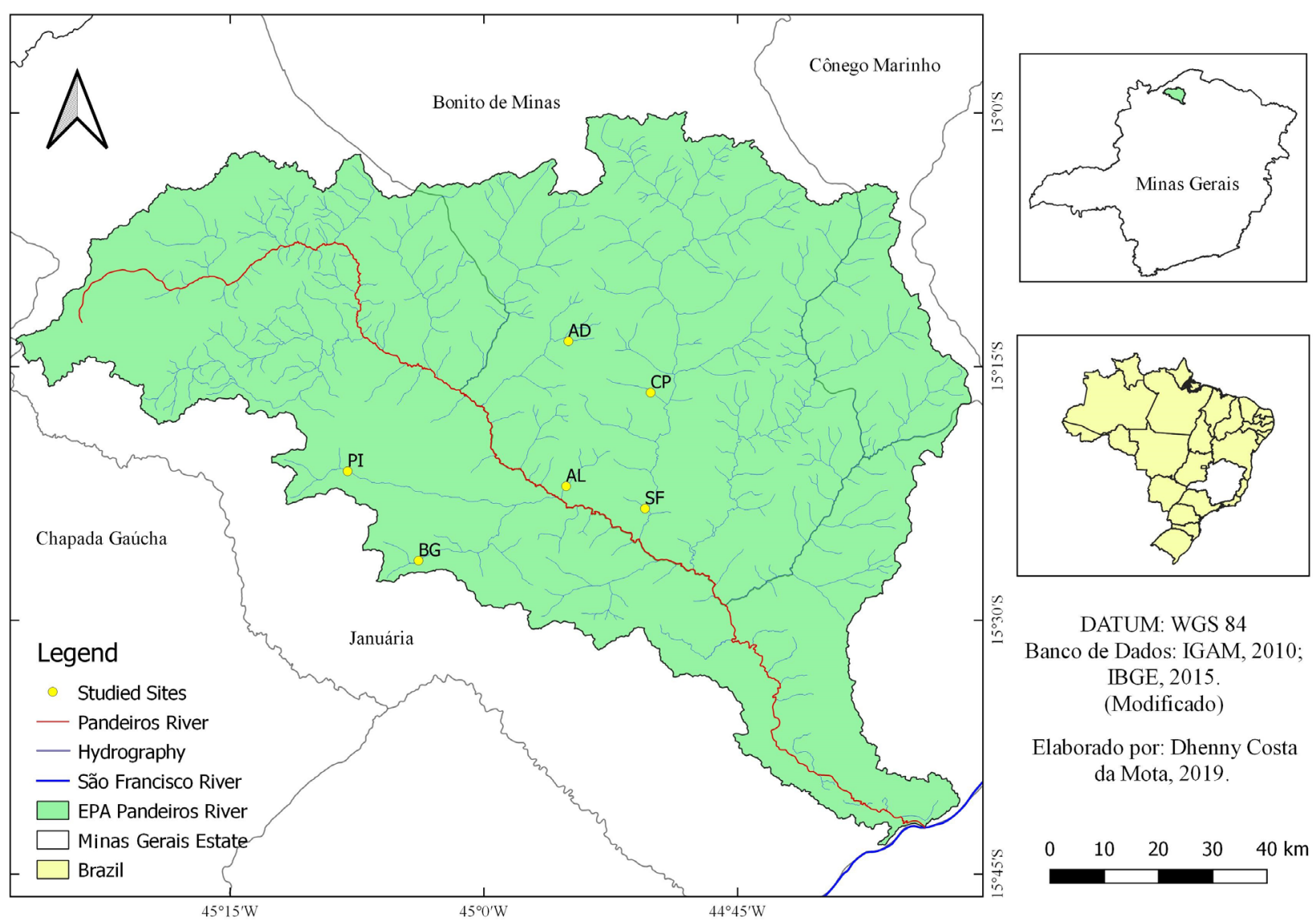

Figure 1. Location of the swamp forests studied (AD, AL, BG, CP, PI and SF) in the Pandeiros River EPA, in northern Minas Gerais State, Brazil. 
Table 1. Descriptions of the six swamp forests in the Rio Pandeiros EPA in northern Minas Gerais State, Brazil. Total area in hectares (Neves, 2011); average height of trees in meters; and number of zones (Araujo et al., 2002).

\begin{tabular}{|c|c|c|c|c|c|c|c|c|c|c|}
\hline Area & Location & $\begin{array}{l}\text { Total } \\
\text { area }\end{array}$ & $\begin{array}{l}\text { Water } \\
\text { flow }\end{array}$ & $\begin{array}{c}\text { Tree } \\
\text { density }\end{array}$ & $\begin{array}{c}\text { Average } \\
\text { height } \\
\text { of trees }\end{array}$ & $\begin{array}{l}\text { Artificial } \\
\text { drainage } \\
\text { channel }\end{array}$ & $\begin{array}{l}\text { Natural } \\
\text { channel }\end{array}$ & Fire & Cattle & Zones \\
\hline $\mathrm{AD}$ & $\begin{array}{c}15^{\circ} 20^{\prime} 03.1^{\prime \prime} \mathrm{S} \\
44^{\circ} 51^{\prime} 00.0^{\prime \prime} \mathrm{W}\end{array}$ & 96 & Stable & Dense & 25 & Absence & Perennial & Absence & Present & Three \\
\hline $\mathrm{AL}$ & $\begin{array}{c}15^{\circ} 21^{\prime} 37.2^{\prime \prime} \mathrm{S} \\
44^{\circ} 54^{\prime} 45.9^{\prime \prime} \mathrm{W}\end{array}$ & 154 & Stable & Dense & 30 & Present & Perennial & Absence & Present & Three \\
\hline SF & $\begin{array}{c}15^{\circ} 23^{\prime} 4.4^{\prime \prime} \mathrm{S} \\
44^{\circ} 50^{\prime} 59.6^{\prime \prime} \mathrm{W}\end{array}$ & 28 & Stable & Dense & 25 & Absence & Perennial & Absence & Absence & Two \\
\hline BG & $\begin{array}{c}15^{\circ} 26^{\prime} 26.6^{\prime \prime} \mathrm{S} \\
45^{\circ} 3^{\prime} 55^{\prime \prime} \mathrm{W}\end{array}$ & 350 & Irregular & $\begin{array}{l}\text { Irregular } \\
\text { sparse trees }\end{array}$ & 8 & Present & Intermittent & Present & Present & Three \\
\hline $\mathrm{CP}$ & $\begin{array}{l}15^{\circ} 16^{\prime} 10.23^{\prime \prime} \mathrm{S} \\
44^{\circ} 51^{\prime} 13.6^{\prime \prime} \mathrm{W}\end{array}$ & 82 & Absent & $\begin{array}{l}\text { Irregular } \\
\text { sparse trees }\end{array}$ & 15 & Present & Intermittent & Present & Present & Three \\
\hline PI & $\begin{array}{l}15^{\circ} 22^{\prime} 30.2^{\prime \prime} \mathrm{S} \\
45^{\circ} 2^{\prime} 0,17^{\prime \prime} \mathrm{W}\end{array}$ & 2,215 & Irregular & $\begin{array}{l}\text { Irregular } \\
\text { sparse trees }\end{array}$ & 15 & Present & Intermittent & Present & Present & Three \\
\hline
\end{tabular}

\subsection{Structural survey of the regenerating community}

We systematically established one hundred $5 \times 5 \mathrm{~m}$ plots (totaling 0.25 ha, distance $15 \mathrm{~m}$ between plots, along the water body) where the regenerating arboreal/shrub individuals having $\geq 1 \mathrm{~cm}$ DGL (diameter at ground level) and $<3 \mathrm{~cm}$ DBH (diameter at breast height - measured $1.30 \mathrm{~m}$ above ground level) were sampled. We measured the DGL and total heights of regenerating individuals using a digital caliper and graduated meter respectively, except for regenerating M. flexuosa palm seedlings, which did not produce visible stipes capable of measurement. The data were collected during dry season.

We collected a sample of each inventoried plant for identification and deposited prepared specimens in the Montes Claros Herbarium (MCMG), at the Universidade Estadual de Montes Claros. Identifications of the collected botanical material were performed by consulting specialists and the specialized literature. The classification system used for botanical families was the Angiosperm Phylogeny Group IV (APG IV, 2016).

\subsection{Data analysis}

We calculated the phytosociological parameters: absolute and relative density, dominance and frequency, and importance value (Mueller-Dombois \& Ellenberg, 1974). The Shannon diversity index $\left(H^{\prime}\right)$ and Pielou equability $\left(J^{\prime}\right)$ were calculated on a natural logarithmic basis (Brower et al., 1997; Magurran, 2011). The Hutcheson $t$-test was performed to compare diversities between areas using the $H^{\prime}$ 'diversity index and PAST program software (Hammer et al., 2001).
We determined the floristic similarities between the sampled areas by comparing their species in a presence/ absence matrix using the Single Linkage method and Euclidean metric distances with Statistica 10 software (Statsoft, 2011). Additive diversity partitioning was examined in 100 permanent plots established in the six areas at different scales. The total species diversity $(\gamma)$ was divided into additive components that represented diversity within the community ( $\alpha$, richness of each plot) and diversity between communities (richness between plots, $\beta 1$, and between areas, $\beta 2$ ). We used the Vegan package for the partitioning of $\alpha$ and $\beta$ diversities in $\mathrm{R}$ (Oksanen et al., 2015; R Development Core Team, 2018). We used a null model with 1000 randomizations to evaluate the statistical significance of the observed values in relation to expected values.

\section{RESULTS}

A total of 5442 regenerating individuals belonging to 134 species, 85 genera, and 47 families were encountered in the six sampled areas (supplementary material). The most important families were Fabaceae, with 21 species, followed by Myrtaceae (11 species), Melastomataceae (10), Clusiaceae (7), and Rubiaceae (5). The genera with the highest number of individuals (57.49\% of the total) were: Xylopia (827 individuals), Miconia (665), Calyptranthes (520), Vernonanthura (454), Zygia (347), and Trembleya (318). The total diversity ( $\mathrm{H}^{\prime}$ ) was 3.38 and the equability (J') 0.69 . The Hutcheson $t$-test demonstrated significant differences in diversity between areas, except for AL and BG $(t=0.842 ; \mathrm{df}=1924.5 ; \mathrm{p}>0.05)$ and $\mathrm{BG}$ and $\mathrm{CP}(\mathrm{t}=23.786 ; \mathrm{df}=1479.2 ; \mathrm{p}>0.01)(\mathrm{Tab} .2)$. 
Table 2. General data of the six swamp forests (AD, AL, BG, CP, PI, and SF) in the Rio Pandeiros EPA (Minas Gerais State, Brazil); Total area in hectares (Neves 2011); NI = number of individuals sampled; $\mathrm{S}=$ richness; $H^{\prime}=$ Shannon diversity index; $J^{\prime}=$ Pielou equitability index; $\mathrm{AB}=$ basal area $\left(\mathrm{cm}^{2} \cdot \mathrm{ha}^{-1}\right)$. Different letters indicate significant differences for the diversity test $(\mathrm{P} \leq 0.05)$.

\begin{tabular}{ccccccc} 
Site & $\begin{array}{c}\text { Total area } \\
\text { (ha) }\end{array}$ & NI & S & $H^{\prime}$ & $J^{\prime}$ & AB \\
AD & 96 & 1404 & 46 & $1.82^{\mathrm{e}}$ & 0.48 & 66.89 \\
\hline AL & 154 & 1210 & 44 & $2.28^{\mathrm{c}}$ & 0.60 & 58.43 \\
BG & 350 & 860 & 29 & $2.23^{\text {cd }}$ & 0.66 & 38.01 \\
\hline CP & 82 & 724 & 30 & $2.07^{\mathrm{d}}$ & 0.61 & 43.04 \\
PI & 2215 & 619 & 44 & $2.93^{\mathrm{b}}$ & 0.77 & 33.91 \\
\hline SF & 28 & 625 & 59 & $3.18^{\mathrm{a}}$ & 0.77 & 34.98 \\
\hline
\end{tabular}

Analyses of each area individually showed that the most abundant species in AD were Xylopia emarginata Mart. (533 individuals) and Calyptranthes brasiliensis Spreng. (514), which showed the highest VI and dominance values, as well as Calophyllum brasiliense Cambess. (83) and Blepharocalyx salicifolius (Kunth) O.Berg (54); 10 species were represented by only a single individual; 82 individuals of $M$. flexuosa were sampled in that area.

The most abundant species in AL were Zygia latifolia (L.) Fawc. \& Rendle (346) and X. emarginata (258), which showed the highest VIs and basal areas, as well as Miconia sp. (200) and Ladenbergia cujabensis Klotzsch (92). Twelve species were represented by only a single individual; 51 individuals of $M$. flexuosa were encountered in that sampling area.

Trembleya sp. (281), Miconia sp. (193), Byrsonima pachyphylla A.Juss. (86), and Aegiphila lhotskyana Cham. (54) were the most abundant species in BG; seven species were represented by only a single individual. Two species of the family Melastomataceae (Trembleya sp. and Miconia sp.) were the most dominant and had the greatest VIs because of their abundances. No regenerating individuals of $M$. flexuosa were found.

In $\mathrm{CP}$ area, the most abundant species were: Vernonanthura phosphorica (Vell.) H.Rob. (317), Tibouchina sellowiana (Cham.) Cogn. (101), and B. pachyphylla (82). Nine species were represented only by a single individual; only five individuals of $M$. flexuosa were encountered in that sampling area. The most abundant species with the highest VI were V. phosphorica followed by B. pachyphylla, due to their large basal areas.

The most abundant species in PI were: $V$. phosphorica (122), L. cujabensis (71), and Ludwigia elegans (Cambess. ex A.St.-Hil.) H.Hara (66); seven species were represented by only a single individual; five individuals of $M$. flexuosa were encountered. As in $\mathrm{CP}$, the most abundant species, and with the highest VI in PI, was V. phosphorica, due to its frequency.

Piper gaudichaudianum Kunth (84), L. elegans (66), Richeria grandis Vahl (63), and Myrsine umbellata Mart. (54) were the most abundant species in SF. The species $P$. gaudichaudianum and M. umbellata had the highest VI, because of the frequency of the former and the basal area of the latter. Twenty-one species were represented by only a single individual; 50 regenerating individuals of $M$. flexuosa were found in SF.

Only two species were common to all six areas: Tapirira guianensis Aubl. and Miconia sp., while 10 species were exclusive to $A D, 11$ to $A L, 22$ to $S F, 11$ to $B G$, seven to $\mathrm{CP}$, and 11 to PI (a total of 72 exclusive species). Floristic similarity showed the formation of a group composed of the BG, CP and PI forests, and another group formed by areas $\mathrm{AD}$ and $\mathrm{AL}$ (Fig. 2). Area $\mathrm{SF}$ was separated from the others.

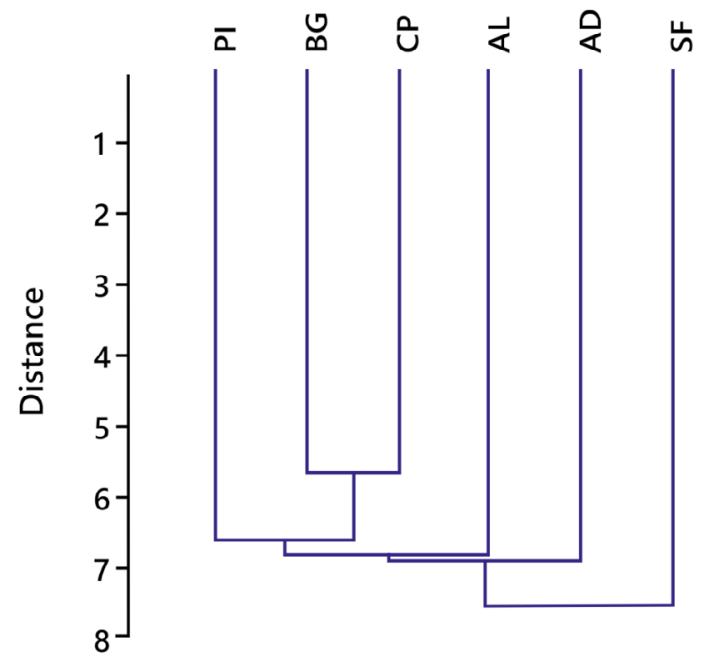

Figure 2. Dendrogram of the floristic similarities of regenerating species in six swamp forests (AD, AL, BG, CP, PI, and SF) in the Pandeiros River EPA, in northern Minas Gerais State, Brazil.

Additive diversity partitioning showed that local species ( $\alpha$ ) are responsible for $4.29 \%$ of the total richness. The exchange of species between plots in each path $(\beta 1)$ represented $36.43 \%$, and the exchange of species between paths ( $\beta 2)$ represented $49.28 \%$ of the total species richness ( $\gamma$ diversity). The diversity of those components was different from that expected by the null model ( $\mathrm{p}=0.001$; Fig. 3 ). 


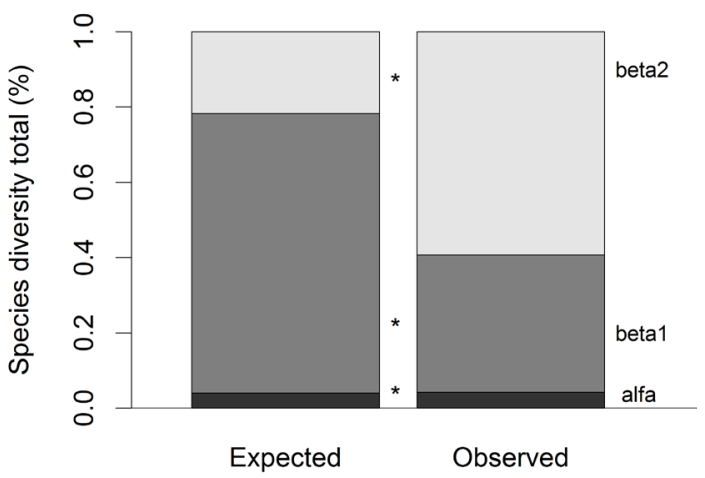

Figure 3. Additive partitioning of $\gamma$-diversity into $\alpha$ and $\beta$ components in 600 plots in six swamp forests in northern Minas Gerais State, Brazil. Observed values were statistically compared with expected values $\left({ }^{*} \mathrm{p}<0.001\right)$.

\section{DISCUSSION}

The swamp forests studied here showed varied structures and compositions, with low similarity between them. Diversity is determined by the numbers of species and their abundances within a community (alpha diversity) and by differences in species compositions and their abundances between areas within the same community (beta diversity) (Magurran, 2011). Beta diversity was thus the component that most explained the total diversity of the swamp forests studied and indicated that each area had a particular flora. The low numbers of species common to those different areas also reinforced that result, because more than half of the species sampled were unique to a single site. Different environmental characteristics, conservation conditions, and land use in each forest can determine those variations, as the areas studied had experienced different anthropic impacts (Neves, 2011) and, consequently, were responding to different degrees of disturbance. The forests in this study experienced external impacts from local inhabitants who use the palm swamps as sources of water, food, and wood, as well as for agriculture purposes (personal observations).

The reduced numbers of species common to all of the forests studied, especially in the same geographic area and watershed, suggest great floristic heterogeneity (Menino et al., 2012). Differences in topography, flooding intensity, and soil conditions at any site will affect the spatial distributions of species and promote phytosociological variations (Teixeira \& Assis, 2011).

Plant diversity in each of the six study areas ( $H^{\prime}$ varied from 1.82 to 3.18 ) was relatively low in relation to the high diversity commonly observed in tropical forests, as swamp forest formations are flooded for most of the year and show low diversity because of those anoxic conditions (Kurtz et al., 2013). Additionally, flooding durations and depths will influence swamp forest compositions (Parolin et al., 2010), as water stress selects for tolerant species that can form large populations, with low resulting diversity (Kurtz et al, 2015).

The Brazilian Cerrado includes forest, savanna, and grassland formations, so that both forest and savanna communities experience the same climate regime (Ribeiro \& Walter, 2008). Soil moisture and fertility levels, as well as geographic proximity, are also important factors contributing to species distributions in those environments (Silva Júnior et al., 2001). Swamp forests, as well as palm swamps, are humid formations within the Cerrado biome, with different surrounding plant communities that will influence their species compositions (Teixeira \& Assis, 2011). The existence of differing Cerrado vegetation types results in numerous species co-occurring throughout the biome, increasing the diversity of any given region. Menino et al. (2012), for example, reported high species diversity between naturally regenerating riparian vegetations in the Pandeiros River study area that was influenced by the occurrence of diverse neighboring vegetation types. In addition to ecological conditions, geographical proximity can also be determinant for floristic composition (Kurtz et al., 2013). The conditions necessary for the establishment of different species in humid forests support the hypothesis that the surrounding vegetation contributes to their varied compositions (Teixeira \& Assis, 2011), resulting in a vegetation mosaic. Although some studies have indicated a group of species characteristic of swamp forests, the contributions of the surrounding vegetation were determinant to the diverse of each study area (Kurtz et al., 2014).

The species sampled were organized into two groups: those found more frequently in poorly drained and flooded sites, such as X. emarginata, Z. latifolia and $R$. grandis (Maas et al., 2015; Garcia et al., 2015; Secco et al., 2015); and those typical of cerrado and forest edges, such as Trembleya sp., T. sellowiana, and B. pachyphylla (Mendonça et al., 2008). Flood regime durations and water depths will influence plant ecophysiology, and will require special adaptations to the periodicity of local anoxic conditions (Kurtz et al., 2013). Thus, species tolerant of waterlogging will define the plant typology, and will be both abundant and frequent. In this study, species such as X. emarginata, C. brasiliensis, Z. latifolia, Miconia sp., and Trembleya sp. were apparently tolerant of soil water saturation, as they were generally very abundant in the regenerative strata of the forests studied. There are groups of species in swamp forests that demonstrate dominance and high densities in saturated soils, composing a group of flooding specialists (Kurtz et al., 2014). Those species significantly contributed to increasing richness in well-drained soils, but less so in terms of their phytosociological parameters. Teixeira \& Assis (2011) indicated that swamp forests generally show 
low plant diversity and are populated by species with high local densities, and identified C. brasiliense and T. guianensis as indicator species.

The high densities of species typical of humid areas in the swamp forests studied here contributed more to the similarities between the six areas that did their floristics (the presence of species represented by just a few or even a single individual) (Kurtz et al, 2015). Our study areas showed expressive numbers of exclusive species, with SF having the largest number (22 species). The SF area is flooded in the center (where the water table surfaces), but dryer along the edges, with the absence of any grassy zone. It therefore shows no typical separation of the swamp forest and cerrado vegetations, with no middle zone (composed mainly of grasses) of palm swamp (Araújo et al., 2002) - which probably allowed the establishment of numerous unique species with varied ecological requirements. The proximity of surrounding vegetation formations, characterized here as the forest-savanna ecotone, explains the co-occurrence of species on soils with different degrees of drainage (Kurtz et al., 2013; 2014; 2015). The varied environmental conditions in swamp forests, particularly in relation to their flooding regimes and topographic variations, allow the establishment of species with different ecological requirements, including generalist species from neighboring areas (Teixeira \& Assis, 2011; Kurtz et al., 2013).

The species X. emarginata (in $\mathrm{AD}$ and $\mathrm{AL}$ ), B. salicifolius and C. brasiliense (in AD); Z. latifolia and Miconia sp. (in AL), and P. gaudichaudianum, M. umbellata, and L. elegans (in SF), were the most important taxa in terms of vegetation structure regeneration in the present study. Those species occur in humid environments, especially in riparian, gallery, and flooded forests, as well as palm swamp forests or wetlands (Ribeiro \& Walter, 2008; Teixeira \& Assis, 2011). The importance of the species B. pachyphylla, V.phosphorica, T. sellowiana, and Landerbergia cujabensis in areas BG, CP and PI, demonstrated the influence of the adjacent vegetations, different soil conditions, and anthropic disturbances in those areas.

In general, the connections between swamp forest in palm swamps and adjacent Cerrado formations favored floristic diversity because they allowed colonization by species with different ecological requirements, thus increasing diversity. Anthropic interferences in the areas (being most intense in areas $\mathrm{CP}, \mathrm{BG}$, and PI), however, also appeared to be a determining factor of diversity.

The present work indicates that the regeneration potentials of the six areas studied are different (as seen in their respective diversities and compositions), so that conservation, management, or restoration strategies for those environments will be complex, and must be associated with a detailed knowledge of the important species in each area.

\section{CONCLUSION}

Floristic compositions varied among the forests studied here, with many species being unique to each site, and their presence was determined mainly by environmental characteristics, the influences of the adjacent vegetation, and anthropic impacts - all leading to low floristic similarity between them. Diversity, however, was generally low, due to ecological conditions linked to water stress. The different areas showed high variations in terms of their species contents ( $\beta 2$ diversity) and represent a major contribution to the total diversity of swamp forests within palm swamps in northern Minas Gerais State, Brazil.

\section{ACKNOWLEDGMENTS}

This research was supported by the Long Term Ecological Research Network (Programa de Pesquisa Ecológica de Longa Duração - PELD-VERE; Process 441440/2016-9) of the National Council for Scientific and Technological Development - CNPq, the Coordination of Superior Level Staff Improvement - CAPES (Process 88887.136273/2017-00) and Supporting Research Foundation of Minas Gerais FAPEMIG (APQ-04816-17). The authors also thank CNPq (308877/2019-5) and FAPEMIG (CRA-PPM-000627-16 and 005639-18) for grants; Promotoria de Defesa do Rio São Francisco and Forest Institute of Minas Gerais (IEF/MG) for support; W.V. Neves, R.A. Souza, H.D. Faria, J.W.V. Silva, G.P. Jesus, E.B. Sena, S.L. Araújo, M.D.M. Veloso, T.O Bahia, G.S. Mota, L.L. Braga, S.A. Coutinho, W.A. Silva, M.H. Oliveira, G.R. Luz, P.F. Santos, M.A.P. Santos, E.B. Sena e S.L. Araújo for their help with the fieldwork.

\section{SUBMISSION STATUS}

Received: 01 Nov. 2019

Accepted: 07 Aug. 2020

Associate editor: Emanuel José Gomes de Araújo (10)

\section{CORRESPONDENCE TO}

\section{Yule Roberta Ferreira Nunes}

Universidade Estadual de Montes Claros (UNIMONTES), Av. Prof.

Rui Braga, s/n, 39401-089, Montes Claros, MG, Brasil

e-mail: yule.rfnunes@gmail.com

\section{REFERENCES}

Alvares CA, Stape JL, Sentelhas PC, Gonçalves J LM, Sparovek G. Koppen's climate classification map for Brazil. Meteorologische Zeitschrift 2014; 22(6): 711-728.

APG IV - Angiosperm Phylogeny Group IV. An update of the Angiosperm Phylogeny Group classification for the orders and 
families of flowering plants: APG IV. Botanical Journal of the Linnean Society 2016; (181): 1-20.

Araújo GM, Barbosa AAA, Arantes AA, Amaral AF. Composição florística de veredas no município de Uberlândia, MG. Revista Brasileira de Botânica 2002; 25(4): 475-493.

Assis RL, Wittmann F. Forest structure and tree species composition of the understory of two central Amazonian várzea forests of contrasting flood heights. Flora 2011; 206(3): 251-260.

Ávila MA, Souza SR, Veloso MDM, Santos RM, Fernandes LA, Nunes YRF. Structure of natural regeneration in relation to soil properties and disturbance in two swamp forests. Cerne 2016; 22(1): 1-10.

Bijos NR, Eugênio CUO, Mello, TRB, Souza GF, Munhoz CBR. Plant species composition, richness, and diversity in the palm swamps (veredas) of Central Brazil. Flora 2017; 236-237: 94-99.

Brower JE, Zar JH, von Ende CN. Field and laboratory methods for general ecology. 4th ed. New York: WCB McGraw-Hill; 1997.

Chazdon RL, Guariguata MR. Natural regeneration as a tool for large-scale forest restoration in the tropics: prospects and challenges. Biotropica 2016; 48(6): 716-730.

Chazdon RL, Vilchez BA, Letcher SG, Wendt A, Sezen UU. Effects of human activities on successional pathways: case studies from lowland wet forests of northeastern Costa Rica. In Hecht SB, Morrison KD, Padoch C (Eds.). The social lives of forests: past, present, and future of woodland resurgence. Chicago, University of Chicago Press 2014.

Fernandes GW, Pedroni F, Sanchez M, Scariot A, Aguiar LMS, Ferreira G, Machado R, Ferreira ME, Diniz S, Pinheiro R, Costa JAS, Dirzo R, Muniz F. Cerrado: em busca de soluções sustentáveis. Rio de Janeiro: Vertente Produções Artísticas, 2016.

Garcia FCP, Fernandes JM, Silva MCR. Zygia in Lista de espécies da flora do Brasil. Jardim Botânico do Rio de Janeiro. [2015]. Available from: <http://floradobrasil.jbrj.gov.br/jabot/floradobrasil/FB23225>

Hammer $\varnothing$, Harper DAT, Ryan PD. PAST: Paleontological statistics software package for education and data analysis. Palaeontologia Electronica 2001; 4: 1-9.

Kurtz BC, Gomes JC, Scarano FR. Structure and phytogeographic relationships of swamp forests of Southeast Brazil. Acta Botanica Brasilica 2013; 27(4): 647-660.

Kurtz BC, Caris EAP, Scarano FR. Heterogeneity of the woody flora of swamp forests in southeastern and Southern Brazil. Check List 2014; 10(6): 1359-1379.

Kurtz BC, Valentin JL, Scarano FR. Are the neotropical swamp forests a distinguishable forest type? Patterns from southeast and Southern Brazil. Edinburgh Journal of Botany 2015; 72(2): 191-208.

Maas P, Lobão A, Rainer H. Annonaceae in Lista de Espécies da Flora do Brasil. Jardim Botânico do Rio de Janeiro. [2015] Available from: $<$ http://floradobrasil.jbrj.gov.br/jabot/floradobrasil/FB110568>

Magurran AE. Medindo a diversidade biológica. Curitiba/Paraná: Editora da Universidade Federal do Paraná, 2011.

Mendonça RC, Felfili JM, Walter BMT, Silva Júnior MC, Rezende AV, Filgueiras TS, Nogueira PE, Fagg CW. Flora vascular do bioma Cerrado: checklist com 12.356 espécies. In: S.M. Sano, S.P. Almeida, J.F. Ribeiro (eds.). Cerrado: ecologia e flora. Brasília (DF); Embrapa Cerrados: 2008.
Menino GCO, Nunes YRF, Santos RM, Fernandes GW, Fernandes LA. Environmental heterogeneity and natural regeneration in riparian vegetation of the Brazilian semi-arid region. Edinburgh Journal of Botany 2012; 69(1): 29-51.

Mueller-Dombois D, Ellenberg, H. Aims and methods of vegetation ecology. New York: John Wiley \& Sons; 1974.

Neves WV. Avaliação da vazão em bacias hidrográficas com veredas, em diferentes estádios de conservação, na APA do Rio Pandeiros MG [dissertação]. Montes Claros, Minas Gerais, 2011.

Nunes YRF, Azevedo IFP, Neves WV, Veloso, MDM, Souza RA, Fernandes GW. Pandeiros: o pantanal mineiro. MG. Biota 2009; 2(2): 4-17.

Nunes YRF, Bahia TO, Ávila MA, Veloso MDM, Santos RM. Florística e fitossociologia das comunidades arbóreas de veredas: um estudo de caso no norte de Minas Gerais, Brasil. In: Eisenlohr PV, Felfili JM, Melo MMRF, Andrade LA, Meira Neto JAA (eds) Fitossociologia do Brasil: métodos e estudos de casos. Viçosa. MG: UFV; 2015.

Oksanen J, Blanchet FG, Kindt R, Legendre P, Minchin PR, O'Hara RB, Simpson GL, Solymos P, Stevens MHH, Wagner H (2015) vegan: Community Ecology Package. R package version 2.2-1. http://CRAN.R-project.org/package=vegan

Oliveira GC, Araújo GM, Barbosa AAA. Florística e zonação de espécies vegetais em veredas no triângulo mineiro, Brasil. Rodriguésia 2009; 60(4): 1077-1085.

Parolin P, Lucas C, Piedade MTF, Wittmann F. Drought responses of flood-tolerant trees in Amazonian floodplains. Annals of Botany 2010; (105): 129-139.

Pastório F, Bloemer H, Gasper A. Floristic and structural composition of natural regeneration in a subtropical Atlantic forest. Floresta e Ambiente 2018; 25(4): e20170446.

R Development Core Team. R: a language and environment for statistical computing. R foundation for statistical computing, Vienna, Austria. [2018]. Available from: http://www.r-project.org.

Ribeiro JF, Walter BMT. As principais fitofisionomias do bioma Cerrado. In: Sano SM, Almeida SP, Ribeiro JF (Eds.). Cerrado: ecologia e flora. Brasília, DF: Embrapa Informação Tecnológica, 2008.

Santos GL, Pereira MG, Delgado RC, Moraes LFD. Padrões da regeneração natural na região de Mar de Morros, Pinheiral-RJ. Floresta e Ambiente 2017; (24): 1-11.

Secco, R.; Cordeiro, I.; Martins, E.R.; Zappi, D. Phyllanthaceae in Lista de Espécies da Flora do Brasil. Jardim Botânico do Rio de Janeiro. [2015]. Available from: <http://floradobrasil.jbrj.gov.br/ jabot/floradobrasil/FB38579>

Silva-Júnior MC. Análise da flora de matas de galeria no Distrito Federal: 21 levantamentos. In: Ribeiro JF, Fonseca CEL, SouzaSilva JC. (Eds). Cerrado: caracterização e recuperação de Matas de Galeria. Embrapa, Planaltina, 2001.

Statsoft. Statistica (Data analysis software system), version 10. www.statsoft.com. 2011.

Teixeira AP, Assis MA. Floristic relationships among inland swamp forests of Southeastern and Central-Western Brazil. Brazilian Journal of Botany 2011; 34(1): 91-101. 